\title{
Causality, Indeterminacy, and Providence: Contemporary Islamic Perspectives from Said Nursi and Basil Altaie
}

Isra Yazicioglu

\subsection{INTRODUCTION}

In a treatise written for the elderly, Muslim theologian Bediuzzaman Said Nursi shares how getting old provoked an existential awakening/crisis. Worried about the transience of life, he asks, "since my physical self is mortal, what good can I expect from fleeting, mortal things? Since I am weak, what can I expect from these powerless things? I need an Eternal, Enduring One and an Everlasting, Powerful One who can solve my problem [of transience]." He seeks to turn to God for help, but notices some resistance:

$[\mathrm{m}] \mathrm{y}$ ego said to my heart: 'We live in a universe where natural causes effect things by their very nature. Everything is connected to a particular material cause. Therefore, for instance, you should expect the fruits from tree, and

I. Yazicioglu $(\bowtie)$

St. Joseph's University, Philadelphia, PA, USA

e-mail: uyazicio@sju.edu

(C) The Author(s) 2022

K. J. Clark, J. Koperski (eds.), Abrahamic Reflections on

Randomness and Providence, https://doi.org/10.1007/978-3-030-75797-7_13 
the harvest from the land. So, what is the point of praying to God for things, especially small things?' (Nursi 2021, 72) ${ }^{1}$

In a world governed by natural causes, Nursi asks, how can one pray to God to attend one's personal needs? If natural causes and laws of nature are the powers running the world, how can we talk about divine providence? In this chapter, I will engage the issue of divine providence in Islam in a way that is attentive to such questions.

The Quran repeatedly talks about signs/indications/clues in the world that point to the oneness of God and His eternal qualities such as power, wisdom, and knowledge (al-asma al-ḥusna). In Quranic discourse, claims about unseen reality are based on these 'signs' (ayāt) from the world. A robust Islamic understanding of divine providence, therefore, needs to be based on these signs in the world. Two salient features of our world signify divine providence: its regularity and its irregularity/inherent unpredictability. On the one hand, our world is extremely ordered, which allows us to conceptualize 'laws of nature' and predict phenomena in advance. On the other hand, we notice irregularity, uniqueness, and unpredictability. How do we make sense of these two intertwined aspects of our world? How can we understand divine providence in such a world? At first sight, it seems as if we must choose between two interpretations: determinism or 'God of gaps.'

Determinism claims that the regularity and consistency of natural phenomena result from necessary and unchanging 'laws of nature.' Apparent spontaneity or exceptions are actually events necessitated by laws, which we are unable to predict due to our imperfect understanding of nature. Determinism is often considered a good ally for religion: a God that created the world as a perfect and immutable system of laws seems more reasonable than a God who makes exceptions to the way He governs the world. On this view, genuine unpredictability and indeterminism (i.e. the idea that exact same conditions may not have same consequences) are threats to religion. Yet, determinism has been rejected by the majority of scholars in the Islamic context, though a small minority such as Ibn Sina (Avicenna) and Ibn Rushd (Averroes) supported it.

\footnotetext{
${ }^{1}$ For an alternate translation of this text see Nursi 1995, 306.
} 
A deterministic interpretation has a major existential cost: the inability to relate the 'details' and unpredictable aspects of the world and our lives to God. Some Aristotelian Muslim thinkers even claimed that such messy aspects on the individual level are unfit for divine agency so, as such, God does not know the particulars. ${ }^{2}$ Such a deterministic approach also has difficulty making room for human freedom or freewill. The existential price is too high: How do I cry out to a Creator who cannot know or care about my 'small' world of needs, yearnings, worries, and choices?' ${ }^{3}$ Moreover, disconnecting particulars from the Creator faces serious intellectual challenges. In an interconnected universe, the 'details' can't be neatly separated from the major things (Nursi 1995, 307-309). Furthermore, determinism is inconsistent with the empirical data that indicate indeterminism, for instance, as discovered in quantum physics. Finally, a religious endorsement of determinism sits uneasily with Quranic passages according to which God's will and choice encompass the smallest details and particulars:

God's alone is the dominion over the heavens and the earth. He creates whatever $\mathrm{He}$ wills: $\mathrm{He}$ bestows the gift of female offspring on whomever $\mathrm{He}$ wills, and the gift of male offspring on whomever He wills. (Q. 42:49)

And among his signs is the creation of the heavens and the earth, and the diversity of your tongues and colors: for in this, behold, there are messages [lit. signs $(a y \bar{a} t)]$ indeed for all who would know! (Q. 30:22) ${ }^{4}$

In contrast with determinism, some people regard irregularity as easier to connect with the divine. On such view, regularity makes the world seem less wonderful and less connected to the Transcendent. Our needs being met in consistent ways (say, our need of energy met through the regular movement of the sun) is not a sign of Transcendent power and care, but our needs being met in miraculous ways (say, a baby surviving in a hurricane against all odds) is a sign. But such focus on irregularity also has a hefty price: giving up regularity as a domain worthy of awe (a sign). Such an approach voids much of ordinary life of significance. It also contradicts

\footnotetext{
${ }^{2}$ Ghazali (2000) strongly criticizes them in 11 th Discussion of his Tahäfut.

${ }^{3}$ For a discussion of how God's all-encompassing will and power make human freewill possible in light of Nursi's approach, see Yazicioglu 2017, 138-142.

${ }^{4}$ All translations from the Quran are based on Muhammad Asad's translation (1984).
} 
the Quranic perspective that considers the ordinary as filled with signs of God.

Contra both views, this paper takes both the regularity and irregularity of the world seriously and interprets them in a coherent and existentially meaningful way. (I use the term 'irregularity' as an umbrella term for phenomena from a buman perspective, in the sense of unpredictability, randomness, and spontaneity.) I explore how two contemporary Muslim scholars offer good examples of such an approach. I start with Nursi (1876-1960), ${ }^{5}$ an important theologian who insightfully reads the Quran in light of nature and vice versa. ${ }^{6}$ Next, I turn to Muhammad Basil Altaie, a contemporary quantum physicist interested in Islamic theological reflection and whose work I interpret in light of Nursi's. I find their approaches promising for several reasons. First, they offer a holistic understanding of reality, attending to both its regularity and irregularity, attending to both its general features and unique particularities. Second, they hold that Quranic discourse offers cues to make sense of our experience of the world. Taking the Quran seriously, they reflect on the world and see how it bears witness to the Transcendent, rather than adjudicating theological statements 'top-down' or as assumptions accepted without empirical evidence. I start with Nursi, whose theological insights provide a helpful framework for enhancing Altaie's contribution.

\subsection{Said Nursi: Causality, Laws of Nature, ANd Indeterminacy as Signs of God}

This section offers a closer look at Nursi's views on natural causality, laws of nature, and Divine will, paying attention to his understanding of regularity and irregularity in the world in light of the Quran. ${ }^{7}$ According to Nursi, one of the main purposes of the Quran is to cut through the 'veil

\footnotetext{
${ }^{5}$ While Nursi's works are extremely significant, political censorship, along with other issues, has limited the transmission of Nursi's scholarship. Nursi's works were been banned in Turkey for much of his career, and after his death, he was often left out of the histories of exegesis and theology of the late Ottoman/early Republican period in Turkish universities. See Tuna 2017, 313-318.

${ }^{6}$ For a background on Nursi and his Quranic hermeneutics, see Bouguenaya and Yazicioglu 2017.

${ }^{7} \mathrm{I}$ am indebted to Dr. Yamina Bouguenaya for explaining Nursi's views as well as her clarification of points on quantum physics, including her lecture on Islam and quantum physics at St. Joseph's University (March 2019).
} 
of familiarity' (ulfa) to make human beings recognize the agency and attributes (such wisdom, power, and the compassion) of the Creator. ${ }^{8}$ Many Quranic passages invite reflection on nature, the way things come into being, and the way they are arranged and ordered so as to see how things point to and praise their Maker. The Quran offers encouragement and cues for such reflection to see the signs/traces/clues of the Divine in the world (Mermer 1996, 279-283). ${ }^{9}$

Nursi seems to start with the 'causal maxim,' the assumption that every new existent requires a cause. If something happens, especially in an orderly fashion, it must have a cause (Nursi 1995, 233-234). On the basis of the 'causal maxim,' we seek causes of events happening around us. Almost by default, we identify certain events or objects as the causes of other events that consistently follow them in time. For instance, when there is water, we see that the seed grows; when there is no water, it does not grow; therefore, we conclude, water gives life. While such inferences are common in everyday life, Nursi suggests that they are mistaken.

Nursi suggests, with other Muslim theologians and mystics, that the Qur'an invites us to dig beneath the surface for an accurate understanding of causation. When people take the time to reflect on the cues provided by the Qur'an, they will realize that what we regard as a causal relationship in nature is a mere conjunction (iqtirān) between natural events, not causation. Put in classical Islamic terminology, what we often regard as a cause is a seeming cause (al-sabab al-zabiri $)$, which points to the real cause (musabbib al-asbāb, 'causer of all causes'):

Heedless people are confused by the conjunction (iqtirān) of things. They assume that if two things appear together, it must be that one is causing and producing the other. This erroneous perception is reinforced by the fact that when the supposed cause is removed, the blessing that came with it disappears, leading people to mistakenly infer that the supposed cause must have created the blessing. With this misunderstanding, they direct their love and gratitude toward the supposed cause rather than to the Real Giver of blessings. (Nursi 1996, 182, emphasis added)

${ }^{8}$ The famous Muslim scholar, Rumi, Jalal al-din (1207-1273), says that the main message of the Quran and the prophets is to challenge and correct our mistaken understanding of causality (see, for instance, Mathnawi, Book 3, 2525).

${ }^{9}$ For an analysis of Nursi's view of causation in the context of Western thought and Islamic history, see Mermer 1996, 243-82. 
Suppose we call such misunderstandings as 'argument from absence,' since it is built on the fact that when $\mathrm{A}$ is absent $\mathrm{B}$ is also absent. We employ such arguments from absence both in everyday life and in scientific theorizing. Most contemporary accounts of causality in Western thoughtregularity accounts, probabilistic accounts, counterfactual accounts, interventionist accounts - are versions of this reasoning; they seek to define causality focusing on either the coexistence of two things (regularity and probabilistic accounts) or on the absence of one in the absence of the other (the counterfactual account). In contrast, Nursi finds such reasoning flawed. Why?

Argument from absence is misleading because what leads to absence of something is not the same as what leads to its existence. For instance, a garden flourishes when many conditions are present, such as, air, bacteria, sunlight, minerals, gravity, and so forth. Yet when only one of these conditions, say water, is absent, the garden does not flourish (Nursi 1996, 181-182). Therefore, co-absence of two things does not necessarily prove that one produces the other. In other words, the argument from absence is misleading, which shows that the fact that a garden does not flourish in the absence of many things cannot prove that these many things cause the garden. Nursi, here, makes a distinction between 'conditions' and 'causes': the fact that a garden comes into existence under certain circumstances is something we observe. But this observation does not demonstrate that the garden is caused or produced by these conditions (either one or many).

In both classical Islamic theology and post-Humean philosophy, the consistent appearance and disappearance of two things cannot demonstrate that one produces the other. It is possible and consistent with empirical evidence that the presence of all these natural things (e.g., sunlight, air, soil, water, certain temperature range, bacteria, movements of the earth and sun, etc.) are only 'a customary condition' for the real cause or agent to create the result.

According to Nursi, the evidence for inferring that divine will and power as the real cause is in the 'mismatch' between 'seeming causes' and their effects. The 'seeming causes' (e.g., sunlight, air, soil, water, certain temperature range, etc.) fall short of bearing responsibility for a wellordered, well-balanced, alive thing, such as a garden:

to attribute a well-ordered and well-balanced being which has unity such as [a living being] to the jumbled hands of innumerable, lifeless, ignorant, aggressive, unconscious, chaotic, blind and deaf natural causes, the blindness and deafness of which increase with their coming together and intermin- 
gling among the ways of numberless possibilities, is as unreasonable as accepting innumerable impossibilities all at once. $(1995,236)$

In other words, 'seeming causes,' even when taken together, do not display the necessary knowledge, contrivance, power, mercy, or life observed in their effects. Nursi offers this reasoning as an exegesis of the Quranic verse: "Those you call on beside God could not, even if they combined all their forces, create a fly" (Q. 22:73).

In a treatise reflecting on nature as sign of God, Nursi summarizes his interpretation of natural causality in light of the Qur'anic discourse:

We look at things which appear to be causes and effects in the universe and we see that the most elevated cause possesses insufficient power for the most ordinary effect. This means that causes are a veil, and something else makes the effects. To take only a small example out of innumerable creatures, let us consider the faculty of memory, which is situated in man's head. ... We see that it is like a book so comprehensive-indeed, like a library - that within it is written without confusion the entire story of a person's life. What cause can be shown for this miracle of power? The grey matter of the brain? The simple unconscious particles of its cells? The winds of chance and coincidence? [Rather] that miracle of art can only be the work of an All-Wise Maker. ... Thus, since they are comparable to man's faculty of memory, make an analogy with all eggs, seeds, and grains, and then compare other effects. (Modified translation, Nursi 2004, 711) (10 $^{2}$

While brain's gray matter is observed in conjunction with memory, it cannot be the creator of memory because of the mismatch between the seeming cause and the result. Conjunction and 'co-absence' (i.e., absence of the consequent upon the absence of the precedent) are factual: (1) one's memory comes into existence with the existence of certain conditions, such as brain cells, and (2) the memory is lost or damaged when any of these conditions is absent (e.g., if certain brain cells get damaged). But this observation does not prove that these natural conditions collectively produce a memory. In order to be the proper cause, one must also consider the alleged cause's attributes. An orderly and powerful result indicates purpose and is interconnected with the rest of the body and a person's lifelong experience in the world; so, either these natural causes are utterly

\footnotetext{
${ }^{10}$ Nursi claims that what we regard as ordinary is in fact extraordinary in that it goes beyond the capacity of natural causes. Altaie likewise suggests that the normal course of nature is miraculous in the sense of being constantly created and recreated.
} 
wise, knowing, and powerful on their own (which they are not) or the cause is a real agent who has comprehensive knowledge, power, and care. Needless to say, Nursi's reasoning rejects the Darwinian claim that the purposefulness and organization in nature is the result of unintentional forces blindly interacting over time. ${ }^{11}$

Nursi also talks about the interconnectedness of created beings. He emphasizes that things come into existence in relation to most, if not all, things in the universe. Nursi notes, for instance, that the eye is in a constant organic exchange with the entire body (including the digestive, respiratory, and urinary systems) as well as with what is outside the body (such as sunlight, visible objects, air pressure, etc.). If things and events in the universe are interconnected, then what is required for the production of a thing or event is not just any knowledge and power but an allencompassing knowledge and power (Nursi 1996, 307). Nursi again gets his cue for this argument from the Qur'an: "Creating and resurrecting all of you is only like creating or resurrecting a single person: God is all hearing and all-seeing” (Q. 31:28).

Nursi suggests that our observation of nature discloses that the Creator creates in two ways:

The first is through origination and invention [ibda']. That is, He [the Creator] brings a being into existence out of nothing, out of non-existence, and creates everything needed for it, also out of nothing, and places those provisions in its hand.

The second is through composition, through art [insha]. That is, $\mathrm{He}$ forms certain beings out of the elements of the universe in order to demonstrate subtle instances of wisdom, like displaying the perfections of His wisdom and the manifestations of many of His Names. Through the law of Providing [qānun al-razzaqiyya], He sends particles and matter, which are dependent on His command, to these beings and employs the particles in them. (Nursi 1995, 253, italics added)

According to Nursi, these two forms of creations are observed within each other.

${ }^{11}$ Altaie also rejects this "blind watchmaker" claim by saying that "if a blind person can make a watch, certainly he is not blind" (Altaie 2014, 79). The endless evidences of purposefulness and comprehensive knowledge in nature is a major reason why the theory of evolution is received with much criticism in the Muslim world, including by many respected and sophisticated Muslim thinkers and scientists in the contemporary era, such as S. Hossein Nasr and Muzaffar Iqbal. For critical analysis of the theory, see Nasr 2009, 184-197, and Bouguenaya et al. 2018. 


\subsubsection{Nursi's Approach to Natural Causality in the Context of Contemporary Theories of Causation}

Relying on the observation that A and B appear consistently together and $\mathrm{B}$ disappears in the absence of $\mathrm{A}$, there are three options for explanation:

1. The regularity is a mere coincidence.

2. A and B are intrinsically/necessarily connected and A has the necessary qualities to produce $\mathrm{B}$.

3. There is an agent outside of $\mathrm{A}$ and $\mathrm{B}$ that connects the two consistently.

Medieval Muslim philosophers, such as Ibn Rushd, considered only the first two options; the third option didn't seem to exist for them (Kukkonen $2000,492)$. The first option didn't make any sense because if the order were "coincidental or accidental, it would not have continued always or for the most part without deviation" (Marmura 1965, 195). So, this minority of medieval Muslim scholars, such as Ibn Rushd, affirmed the second option: A and B go together consistently because A has the powers to necessitate or produce B (Yazicioglu 2013, 35). In contrast, Ghazali, and the majority of Muslim scholars, opted for the third option. Divine will (and power, and wisdom, etc.) connects seeming causes with their 'effects.' Nursi supports this explanation, as we have seen, because of the mismatch between a natural effect and its cause; natural causes cannot be real causes because they lack the knowledge, power, and purposefulness needed to produce their effects.

Steven Nadler notes that Hume's argument that there is 'no necessary connection' between a natural cause and its effect is fundamentally the same as Ghazali's critique of option 2. ${ }^{12}$ However, having rejected 2, Hume did not affirm 3, either. Ultimately, Hume shied away from any explanation. Contemporary (Hume-influenced) theories of causation offer no alternatives to the three main options as they limit themselves to mapping the coexistence and co-absence of things. ${ }^{13}$ Despite their sophistication and technical detail, contemporary theories of causation show that there is nothing new under the sun.

\footnotetext{
${ }^{12}$ Steven Nadler, Occasionalism: Causation Among the Cartesians, New York: Oxford University Press, 2011, 167. Hume's account is also similar to Autrecourt and Malebranche's.

${ }^{13}$ That is why, a variety of contemporary philosophical accounts, such as regularity theories of causation and counterfactual theory, are compatible with the occasionalist explanations (Quinn 1988, 55-64).
} 
A common worry is that if we were to accept 3 , we would lose scientific inquiry. Such worry is mistaken. Science is possible in 3 because divine agency isn't opposed to 'seeming causes.' Rather, 'seeming causes' are understood as conditions under which the Wise Creator chooses to create consistently. Finding out seeming causes remains important. In fact, Nursi suggests that obeying the 'protocols' of the natural order with the awareness that God is the causer of all causes is a form of worship (Yazicioglu 2013, 144-145), and having recourse to 'seeming causes' is a form of 'prayer' to God, who alone creates the results (Nursi 2021, 116-119). Can one accept 3 without inferring God's continuous act of creation? Could something else other than divine agency connect A and B consistently? We shall explore this in the next section.

\subsubsection{Nursi on Laws of Nature}

Few contemporary thinkers defend the notion that natural causes have intrinsic, agential powers to create things. Similarly, modern scientific theories assume natural laws, rather than essences, make things burn or the law of gravity makes things fall-an explanation often misconstrued as an alternative to divine agency.

According to Nursi, attributing agency to laws of nature is mistaken because laws of nature are theoretical constructs that describe-or attempt to describe-regularities observed in nature; they do not cause those regularities. Indeed, a natural law is a description of a regularly occurring event and the description cannot be taken as the cause of the event itself (Mermer $1996,244)$. Consider a mother who makes pancakes every Sunday morning. Her child, noticing the regularity of this event, infers a "Sunday pancake rule" by which he successfully predicts the Sunday breakfast menu. However, the "Sunday pancake law" is not independent of the mother's agency; the law has no efficacy on its own. It would be folly for the child to suggest that the "Sunday pancake law," not his mother, makes the pancakes. Nursi would agree with American philosopher Charles S. Peirce (1839-1914) who noted that "No law of nature makes a stone fall, or a Leyden jar to discharge, or a steam engine to work." As Peirce puts it:

a law of nature left to itself would be quite analogous to a court without a sheriff ... let a law of nature-say the law of gravitation-remain a mere uniformity - a mere formula establishing a relation between terms - and what in the world should induce a stone, which is not a term nor a concept but just a plain thing, to act in conformity to that uniformity? (Peirce [1903] 1931-58, 5.48, emphasis added) 
Regularity in the world needs an agent to make things happen: either the stones know the formulas and have the power to act accordingly or an agent with comprehensive knowledge, will, and power puts these 'laws' into effect. Laws of physics are descriptions of the regularities by which the world is governed by the Creator; while such formulations are helpful for making predictions, they cannot replace the need for a Creator. ${ }^{14}$

In addition to arguing that 'laws of nature' cannot operate on their own, Nursi notes that they do not describe the world completely. That is, exceptions to the laws of nature are not impossible; all laws of nature, Nursi notes, have exceptions (say, the virgin birth, a miracle, to the 'law of reproduction'). Nursi's approach here is reminiscent of Peirce's principle of 'tychism,' according to which there is a degree of 'spontaneity' in nature, and that natural laws are not absolute. Peirce notes that the empirical data, such as diversity, consciousness, and growth, support tychism rather than determinism or necessitarianism (Yazicioglu 2013, 110-111).

Nursi states similar points when responding to a question about a Quranic verse, known as 'the verse of the five unknowns' (al-mughayyabāt al-khamsa): "Truly, with God alone rests the knowledge of the Hour, and it is He who sends down the rain; and He knows what is in the wombs. No soul knows what it will earn tomorrow, and no soul knows in what land it will die. Truly, it is God who is all-knowing, all-aware" (Q. 31:34). Nursi contends that there are two types of occurrences in the universe: (1) the ones that come into existence according to a regular pattern, like the sunrise; and (2) the ones that come into existence without a regular timetable, like rainfall. Regular events in the universe point to God's power and wisdom and show that things do not happen haphazardly, that there is a purposeful and wise creator creating them in order. At the same time, the irregularity and diversity in the world point to divine choice and will. In other words,

The All-Powerful \& All-Knowing One, the All-Wise Maker, shows His power and His wisdom and that chance can in no way interfere in His works through the order and regularity with which he governs the world. Such order and regularity manifests in the form of laws [in nature.] At the same time, through exceptions to the laws, the breaks in established patterns,

${ }^{14}$ Otherwise, we would have to explain how "mindless bits of matter behave in a consistent and coordinated way" (Frederick 2013,269). The minority who claim that laws of nature do have agency (such as Nancy Cartwright) acknowledge that such a view makes sense only if there is a divine agent. 
changes in appearances, differences in individual characteristics, and changes in the emergence [of blessings], He shows His volition, will, choice, and that $H e$ is an agent with choice, and $H e$ is under no restrictions whatsoever. (Nursi 2004, 217, emphasis added $)^{15}$

Using the example of a baby in the womb, Nursi explains how regularity and uniformity complement the irregularity and uniqueness of phenomena in the world which together point to the names of God. On the one hand, there is a uniform aspect, a regular pattern to the growth of a fetus, from which we reliably predict that a human fetus will share basic features with other human beings. On the other hand, there is a non-uniform aspect to each fetus, such as her specific features, personality, and unique potentials. These special aspects of the fetus, which cannot be known in advance, point to the free will and choice of its Maker. In sum, from a Quranic perspective, irregularity in the world - such as the timings of rainfall, the particular life journey of a human being, the hidden potential of a baby in the womb, or the life span of each individual-discloses the special will and choice of their Maker and shows that His mercy and power are not limited. ${ }^{16}$

After having explored Nursi's approach to order and irregularity in nature in light of the Quran, let us now engage with Muhammad Basil Altaie's work.

\subsection{Quantum Physics Interpreted: Altaie on Laws of Nature, Indeterminism, and Causality}

As a quantum physicist, Altaie holds that quantum indeterminacy supports Islamic theism. ${ }^{17}$ According to Altaie, like for Nursi, our world is both highly predictable-hence we are justified in talking about 'laws of nature'-and indeterministic - which enables us to appreciate that these laws are not absolute. ${ }^{18} \mathrm{He}$ sees the order of nature as a sign of Divine

\footnotetext{
${ }^{15}$ Modified translation. See original text in Nursi 1996, 76.

${ }^{16}$ What are the implications of continuous creation for 'the problem of evil'? For a discussion of classical Islamic theology in this context, see Yazicioglu 2017, 137-138. For Nursi's views, see Bouguenaya 2014. See also Yazicioglu 2021.

${ }^{17}$ Altaie uses "indeterminacy" similar to my use of "irregularity" or "spontaneity" when discussing Nursi's approach. Altaie means indeterminate in the sense of not being predictable by human beings, not in the sense of being uncaused by any agent.

${ }^{18}$ Altaie seems not to have read Nursi as there are no references to Said Nursi in his book.
} 
wisdom and the unpredictability as an indication of continuous creation. In what follows, I unpack how he arrives at these conclusions.

\subsubsection{Genuine Indeterminacy in Nature}

Altaie interprets indeterminacy of nature in light of an Islamic theological framework. ${ }^{19}$ According to most quantum physicists the world is in some ways genuinely irregular, not just apparently so due to our ignorance of relevant laws (Koperski 2015, 160-161). Altaie agrees, noting that quantum indeterminacy is well-established on the basis of empirical data:

This indeterminism is not an artifact of the theory, it is something that is inherent in natural phenomena. ... For example, the observation that particles behave like waves is an experimental fact that has been shown through particle diffraction experiments in laboratories. The fact that electrons tunnel through potential barriers that are higher than their energies is a fact that is observed in semiconductor devices, without which our mobile phones and computers would not work. Even the superposition of states and their non-locality, entanglement and the most bizarre phenomena have all been observed in laboratories. (Altaie 2016, 75)

While some physicists resist the indeterministic implications of the empirical data, Altaie affirms the dominant view that the natural world is genuinely ontologically indeterminate (not simply epistemically indeterminate).

Quantum mechanics, Altaie notes, applies both to microscopic and macroscopic reality. Indeed, he writes, "on a highly detailed scale, all systems behave quantum mechanically, it is only that we cannot feel the quantum effects on a large scale" (Altaie 2016, 77). Macro- and microlevel physics are perspectives on the same reality. Noting this is helpful from an existential perspective in that, as Nursi suggested earlier, the entire universe including its details must be connected to the same Creator.

According to Altaie, quantum indeterminism suggests that the world needs more than just an agent to get it all started (unlike Aristotle's prime mover). Indeed, indeterminism indicates that the world needs to be created and recreated at every moment. According to determinism, the prior

${ }^{19}$ Altaie's method of starting with scientific data and exploring their metaphysical implications reminds me of Peirce's search for "a properly executed metaphysics" or "scientific metaphysics." See Yazicioglu 2013, 152-156. 
conditions necessarily determine the events that take place; once the prior conditions are set, the next steps issue from them without need for an agent. ${ }^{20}$ In contrast, "by moving away from classical determinism, we discover that the making of an event or a process takes much more than the required conditions and goes beyond the power of the individual entities that contribute to the event" (emphasis added). In other words, through quantum physics we recognize that prior conditions are insufficient to determine what comes next and that reality is interconnected with the rest of the universe. Therefore, there must be "an agent that dominates the whole universe with a plan and ... power that makes it possible to have an ordered world ruled according to present laws that we recognize by watching the world's phenomena" (emphasis added). Since a simple 'operator' to switch between several options would prove inadequate, we need an all-knowing and all-powerful being to sustain the world within this dynamic, indeterministic, and yet overall consistent reality (Altaie $2016,37) .{ }^{21}$

In order to appreciate Altaie's interpretation of quantum indeterminacy as indicating an all-powerful and all-knowing God, we must understand what he makes of natural laws and natural causes. Would he agree with the view that the laws of nature and causal powers of the objects decrease or even obviate the need for a Creator to continuously create the world?

\subsubsection{Altaie on Laws of Nature}

According to Altaie, there are two problems with the claim that the laws of nature explain the world without the need for a Creator. First is "the problem of operation." Like Nursi and Peirce who pointed out the laws of nature have no agency, Altaie notes that laws of nature cannot operate on their own: "Some agency has to drive these laws in accordance with the algorithm they describe" (Altaie 2014, 30). Second is "the problem of coordination" because physical laws "often contradict each other" and cannot coordinate each other, yet we see that they are coordinated for "a fruitful result" (Altaie 2005, 80). "Fruitful result" likely refers to

\footnotetext{
${ }^{20}$ Determinism may be why some claim that the nature is 'autonomous' or operates on its own after having been created. Such a view is difficult to reconcile with the theistic belief that the world is constantly dependent on the Creator. As Quinn suggests continuous creation is more compatible with theism than often assumed (Quinn 1988 and Freddoso 1988).

${ }^{21}$ According to Altaie, while scientists need not to talk about such a being, human beings can and should (Altaie 2016, 37).
} 
purposeful results, as in the fine-tuning of the world for life and the wise planning of living beings. Laws of nature do not have "the power, intelligence, planning and hindsight to act and produce the results that they are acting for" (Altaie 2016, 43).

Altaie also makes an interesting distinction between 'laws of nature' and 'laws of science' (e.g., laws of physics). He uses 'laws of nature' to refer to the regularities in the world, while 'laws of science' are human attempts at representing the former in mathematical terms. While there is a correspondence between the two, the latter is always an incomplete task due to what humans do not-or cannot-know. There is also sometimes dissonance between the two. For instance, mathematical equations in laws of science are time-reversible but the phenomena they describe are not time-reversible (Altaie 2016, 34). Similarly, a formula may be deterministic but its represented reality may not be, such as the Schrodinger equation describing indeterministic quantum phenomena (Altaie 2016, 47). ${ }^{22}$ While the distinction between 'laws of science' and 'laws of nature' is not essential for this paper, it is still helpful. It enables caution about metaphysical claims. Just because a scientific theory works well by allowing us to predict things accurately and build new technology, does not mean that it provides a good understanding or explanation of reality.

\subsubsection{Causality: First and Second Level of Analysis}

For Altaie, seeking causal connections between events is the business of science, and without identifying causes and effects we would not be able talk about the order in the world. We infer causal connections on the basis of the regularities we observe in world events, such as "the free fall of a stone toward the center of the earth, the igniting of a material as it nears a source of heat, or the recovery from illness after taking medicine," which indicate that there are "essential parameters and conditions [which] are causes of the occurrence of the related effects" (Altaie 2016, 51). Yet, it is clear to me that Altaie goes beyond such first-level discussions of causality, in which he uses the term "cause" in a practical sense (as a superficial understanding of causality), and addresses a deeper level, where he explores

\footnotetext{
${ }^{22}$ Just because our formulas are helpful doesn't mean naturalistic assumptions we happen to hold are true. Moreover, theistic interpretations need to be humble because our limited and imperfect representations of nature in mathematical formulas should not be taken to represent 'the mind of God' (Altaie 2016, 48).
} 
the "real" cause that produces or creates the effects. If the first level were explanatory, deeper or second-level analysis would not be needed, but, according to Altaie, the first level is not satisfactory as explanation, even if it may be useful in predicting events and obtaining benefits.

According to Altaie, the identification of an object or event as a cause of another is never certain, because it is hard, if not impossible, to identify all the contributing causes to an event (Altaie 2016, 55). Besides, the regular association of $\mathrm{A}$ with $\mathrm{B}$ and temporal precedence of $\mathrm{A}$ to $\mathrm{B}$ do not necessarily equal causation, as there are cases where this obtains and yet $\mathrm{A}$ is not the cause of $\mathrm{B}$ (when both are caused by something else, as in the case of celestial positions and climate) (Altaie 2016, 57-58). Moreover, if by 'causality' we mean identifying a prior set of necessary and sufficient conditions for an event, such identification is always open to revision. For instance, according to Newton's theory of gravity, the necessary condition for two bodies attracting each other is that "both should have a mass and that they should be separated by finite distance." Such conditions are not necessary in Einstein's theory of gravity. Therefore, while the cause of attraction between bodies is the masses of the objects in Newton's theory, in Einstein's theory the cause is the spacetime curvature (Altaie 2016, 55). From a technical perspective (the 'first level' or superficial analysis of causality), such revisions are not a problem. Newton's theory has served us well and continues to serve well in dealing with macro structures, while Einstein's theory serves us well in predicting cases where the object-such as a light wave-has no mass. However, from an interpretive (deeper/ explanatory analysis of causality), such revisions are instructive. Such shifts in identifying causes, or seeming causes, illustrate that the helpfulness of identifying them does not prove that they are the actual cause. Therefore, it is not surprising that Altaie raises the question whether natural causes are the 'real' causes: "Without [natural] causality, the universe becomes a chaotic one where nothing is predictable. However, the most important question in this topic is: Do causes produce their effects directly? Is the cause just a representation of the reason for what happens, without being effective itself, or is the cause actually the agent producing the resulting effects?" (Altaie 2016, 56, emphasis added).

In other words, Altaie is affirming causes in the practical, superficial

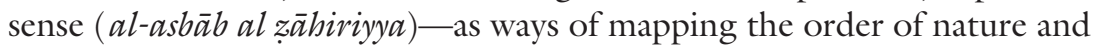
as a heuristic device for predicting and making use of the natural orderand asking the core question of Islamic context: are these causes efficacious on their own or are merely conditions/formalities/occasions within which the real cause ('Causer of all Causes') creates? 
From a determinist perspective, a cause acts necessarily. The idea is that "once an efficient cause exists, all things being equal, its characteristic effect must occur. This means not only that the effect does occur as a matter of fact, but that it cannot fail to do so, because it is necessitated or compelled to occur" (Kogan 1985, 3, emphasis added). ${ }^{23}$ Similarly, Hume highlighted that necessity is part of the definition of cause; cause is that which precedes the effect and necessarily so. Within such deterministic framework, therefore, indeterminacy is considered a major challenge: how can the same conditions not yield the same results?

In contrast, according to Altaie, natural causes are not effective on their own but are simply conditions under which God chooses to create certain results. By God's sunna or custom of creating order we can expect regularity-without claiming that particular order is absolute. The fact that certain things are indeterministic is therefore not a problem, rather it is instructive; indeterminacy teaches us that the Creator is a free agent. According to Nursi, recall, the indeterminacy of events discloses the choice and will of the Creator. Similarly, according to Altaie, the indeterminacy of quantum mechanics provides reason to believe that the universe is continuously created and recreated at every moment by divine will—as prior conditions are unable to determine what happens next.

\subsubsection{Re-creation: An Interpretation of Indeterminism}

Altaie suggests that puzzling features of quantum physics such as the measurement problem, quantum entanglement, non-locality, and quantum coherence comport well with the classical Islamic notion of continuous creation, according to which the world is recreated by God at every moment. He suggests that if we were to form postulates inspired by continuous creation, we would make better sense of the quantum world and may even find venues to further our exploration of it. He offers two such postulates: "all physical properties of microscopic systems are subject to continued creation" and "the frequency of re-creation is proportional to the total energy of the system" (Altaie 2016, 105). Altaie discusses how

\footnotetext{
${ }^{23}$ Ghazali (and Nursi) questioned such an approach and argued that such necessity cannot be proven only on the basis of constant conjunction. What we take to be causes are merely the conditions under which God consistently creates certain results; if God so wishes, He can disconnect the two - though given His wise plan for this world (ijra al-' $\bar{a} d a b)$, God seldom does. For a discussion of the possibility of science and common sense in Ghazali's thought, see Yazicioglu 2013, 32-26.
} 
the explanatory power of such postulates is stronger than current interpretations of quantum theory, such as 'the hidden variables interpretation' or 'multi-world interpretation,' both of which also make metaphysical assumptions - assumptions that lie beyond observation (Altaie 2016, 116).

In interpreting indeterminacy, Altaie proposes the term 'contingent' to replace the term 'random.' This switch suggests that events in the quantum world are not random in the sense of being uncaused, haphazard, or unintended. Instead, they are contingent, in the sense of being dependent on Divine will and power at all times. As the metaphysical explanation that "provides the driver for these laws [of nature], God is not a spectator but a fully active driver who re-creates, prescribes laws that He respects, and ... selects the outcome" (Altaie 2016, 110). Altaie rightly concludes, that God "is not playing dice, but the outcome of His actions causes the dice play” (Altaie 2016, 114).

\subsection{Conclusion}

Understanding divine providence requires understanding the natural order and our place in it. Such inquiry leads to a rethinking of what we usually construe as explanation, especially the causal explanations we employ in everyday life and in modern science. Nursi offers an insightful example of how to do that rethinking and Altaie's analysis of quantum mechanics supports it. In light of cues from the Quran, one can pay attention to empirical data and offer interpretations that are intellectually and existentially compelling.

Nursi and Altaie analyze both the capacities of natural causes and the 'agency' of laws of nature. They interpret the regularity and predictability of the world as a sign of a Transcendent agent with comprehensive wisdom, knowledge, and power. They also resist reifying regularity into absolute laws. Instead, they welcome the unpredictability of the universe as a sign that reveals divine will. Certain things are inherently unpredictable from our perspective because they are dependent on the will of God. ${ }^{24}$

\footnotetext{
${ }^{24}$ Ghazali (on divine will) 2000, 22-24. Similarly, Nursi notes that choice without a determinant is possible, the "function of will is precisely that" (Nursi 2004, 365, modified translation). In the context of making hard choices, Ruth Chang suggests the same: our freewill means our ability to choose without any reasons, which "frees us from the dictatorship of given reasons" (Chang 2017, 20).
} 
Consider the existential implications. Divine freedom frees us from slavery to impersonal, deterministic laws of nature. We can turn to the Creator in our everyday circumstances with our particular needs. This is a world which is governed according to "universal laws and general principles" so as to manifest Beautiful Names (al-asma al-husna) and there is also room for flexibility because "within those universal and general principles [the Creator] has special favours, special succour, special manifestations, so that everything may seek help from Him and look to Him at all times for every need" (Nursi 2004, 684-685, modified trans., emphasis added). To answer Nursi's question that the paper started with: yes, it makes sense for human beings to cry out to God about their particular needs. Indeed, from an Islamic perspective, only the one who sustains the world in its details can hear and respond to human heart's yearning for eternal happiness. ${ }^{25}$

\section{BiBLIOGRAPHY}

al-Ghazali, Abu Hamid. 2000. The Incoherence of the Philosophers: "Tahāfut al-falāsifa”: A Parallel English-Arabic Text. Translated and annotated by Michael E. Marmura. Provo: Brigham Young University Press.

Altaie, Muhammad Basil. 2014. Paving the Way for the Reformation of Islam: Conversation with Mohammed Basil Altaie. In Islam and the Quest for Modern Science, ed. Stefano Bigliardi, 71-102. Istanbul: Swedish Research Institute.

- 2016. God, Nature, and the Cause: Essays on Islam and Science. USA: KRM Publications.

Asad, Muhammad. 1984. Trans. The Message of the Qur'an. Gibraltar: Dar al-Andalus.

Chang, Ruth. 2017. Hard Choices. Journal of the American Philosophical Association 3 (1): 1-21. https://doi.org/10.1017/apa.2017.7.

Freddoso, Alfred J. 1988. Medieval Aristotelianism and the Case Against Secondary Causation in Nature. In Divine and Human Action: Essays in the Metaphysics of Theism, ed. Thomas V. Morris, 74-118. Ithaca/London: Cornell University Press.

Frederick, Danny. 2013. A Puzzle About Natural Laws and the Existence of God. International Journal for Philosophy of Religion 73 (3): 269-283.

${ }^{25} \mathrm{I}$ am grateful for the opportunity to write this paper during the three-year John Templeton-funded research project led by Kelly James Clark. Many thanks to him and to the colleagues in this project. Special thanks to Yamina Bouguenaya and Karen Zwier for stimulating conversations, and to Jeff Koperski, Marilee Coetsee, Emil Salim, and Sajjad Rizvi for their comments. 
Halevi, Leor. 2002. The Theologian's Doubts: Natural Philosophy and the Skeptical Games of Ghazali. Journal of the History of Ideas 63 (1): 19-39.

Kogan, Barry. 1985. Averroes and the Metaphysics of Causation. Albany: SUNY Press.

Koperski, Jeffrey. 2015. The Physics of Theism: God, Physics, and the Philosophy of Science. Singapore: Blackwell Wiley.

Kukkonen, Taneli. 2000. Possible Worlds in the Tabāfut al-falāsifa: Al-Ghazālī on Creation and Contingency. Journal of the History of Philosophy 38 (4): 479-502.

Mackie, J.L. 1965. Causes and Conditions. American Philosophical Quarterly 12: 245-265.

Marmura, Michael. 1965. Ghazali and Demonstrative Science. Journal of the History of Philosophy 3 (2): 183-204.

Mermer, Yamina Bougeuenaya. 1996. Induction, Science and Causation: Some Critical Reflections. Islamic Studies 35 (3): 243-282.

- 2004. Bediuzzaman Said Nursi's Scriptural Approach to the Problem of Evil. Journal of Scriptural Reasoning 4: 1 (online source).

—. with Isra Yazicioglu. 2017. Said Nursi's Qur'anic Hermeneutics. In The Companion to Said Nursi Studies, ed. Ian Markham and Z. Sayilgan, 51-66. Eugene: Pickwick Publications.

- with Isra Yazicioglu and Ilhan Akan. 2018. Facts vs. Interpretations: Understanding Islam and Evolution. Receiving Nur \& Yaqeen Institute for Islamic Research (online source). Available at https://www.receivingnur.org/ understanding-islam-and-evolution.html

Nadler, Steven. 2011. Occasionalism: Causation Among the Cartesians. New York: Oxford University Press.

Nasr, S. Hossein in conversation with Muzaffar Iqbal. 2009. On Biological Origins. In Islam, Science, Muslims and Technology, 184-197. Islamabad/ Karachi: Dost.

Nursi, Bediuzzaman Said. 1994. The Letters: From the Risale-i Nur Collection. Translated by Şükran Vahide. Istanbul: Sözler Neşriyat.

- 1995. The Flashes: From the Risale-i Nur Collection. Translated by Şükran Vahide. Istanbul: Sözler Neşriyat.

- 1996. Risale-i Nur Külliyatı. Vol. 1. Istanbul: Yeni Asya Yayinlari.

- 2004. The Words: From the Risale-i Nur Collection. Translated by Şükran Vahide. Istanbul: Sözler Neşriyat.

- 2021. Living the Quran with Joy and Purpose: Selections on Tawhid from Said Nursi's Epistles of Light. Translated with introduction and notes by Yamina Bouguenaya and Isra Yazicioglu. Piscataway, NJ: Gorgias Press.

Peirce, Charles. 1931-58. The Collected Papers of Charles Sanders Peirce, ed. Charles Hartshorne and Paul Weiss, vol. 5. Cambridge: Harvard University Press. Online edition available from Intelex Past Masters at http://www.nlx.com 
Quinn, Philip L. 1988. Divine Conservation, Secondary Causes, and Occasionalism. In Divine and Human Action: Essays in the Metaphysics of Theism, ed. Thomas V. Morris, 50-73. Ithaca/London: Cornell University Press.

Rumi, Mawlana Jalal al-din. 1929. Mathnawi, Book III. Translated by R.A. Nicholson. London: Gibb Memorial Trust.

Taftazani, Sad al-din.1950. A Commentary on the Creed of Islam: Sa'd al-Din alTaftazani on the Creed of Najm al-Din al Nasafi. Translated with introduction and notes by Earl Edgar Elder. New York: Columbia University Press.

Tuna, Mustafa. 2017. At the Vanguard of Contemporary Muslim Thought: Reading Said Nursi into the Islamic Tradition. Journal of Islamic Studies 28 (3): 311-340.

Turner, Colin, and Hasan Horkuc. 2009. Said Nursi: Makers of Islamic Civilization. Oxford: I.B. Tauris.

Yazicioglu, Isra. 2013. Understanding the Qur'anic Miracle Stories in the Modern Age. University Park: Penn State University Press.

. 2017. A Graceful Reconciliation: Said Nursi on Free Will and Destiny. In The Companion to Said Nursi Studies, ed. Ian Markham and Z. Sayilgan, 129-145. Eugene: Pickwick Publications.

- 2021. Qur'anic Miracle Stories: Surprising Implications for Theodicy, Transience, and Freedom. In Miracles: An Exercise in Comparative Philosophy of Religion, ed. Karen Zwier, David Weddle, and Timothy Knepper. Cham: Springer.

Open Access This chapter is licensed under the terms of the Creative Commons Attribution 4.0 International License (http://creativecommons.org/licenses/ by $/ 4.0 /$ ), which permits use, sharing, adaptation, distribution and reproduction in any medium or format, as long as you give appropriate credit to the original author(s) and the source, provide a link to the Creative Commons licence and indicate if changes were made.

The images or other third party material in this chapter are included in the chapter's Creative Commons licence, unless indicated otherwise in a credit line to the material. If material is not included in the chapter's Creative Commons licence and your intended use is not permitted by statutory regulation or exceeds the permitted use, you will need to obtain permission directly from the copyright holder.



